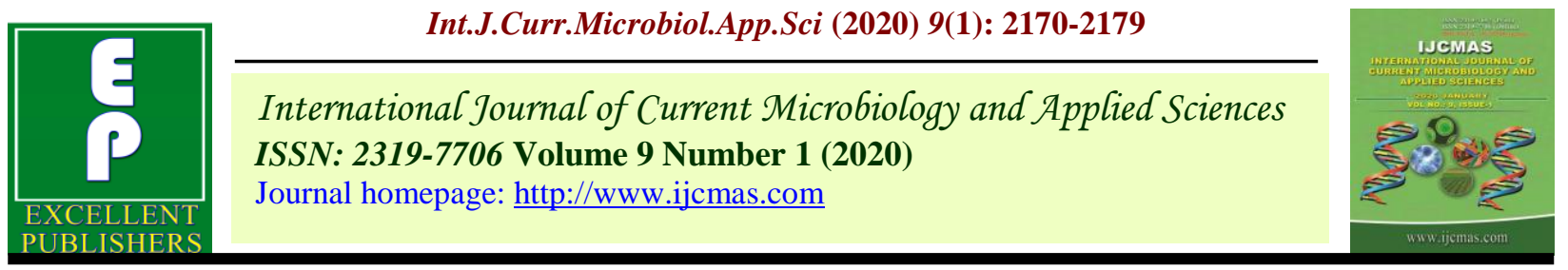

Original Research Article

https://doi.org/10.20546/ijcmas.2020.901.247

\title{
Awareness and Adoption of Urea-Molasses Multi Nutrient Block (UMMB) technology in field situations of Punjab, India
}

\author{
Vidya Nimbalkar*, H.K. Verma and Jaswinder Singh \\ Department of Veterinary and Animal Husbandry Extension Education, \\ Guru Angad Dev Veterinary \& Animal Sciences University, Ludhiana (Punjab), India \\ *Corresponding author
}

Keywords

UMMB

Technology,

Awareness,

Adoption, Dairy

farmers, Punjab

Article Info

Accepted:

22 December 2019

Available Online:

20 January 2020

A B S T R A C T

Uromin-lick (UML)/ Urea-molasses multi nutrient block (UMMB) is a convenient and inexpensive technology providing a range of nutrients to animals. It improves the digestion of low-quality roughages and acts as a blend of energy, protein and minerals. Highlighting the advantages of this technology, the present study was planned to assess the awareness and adoption of the same in field situations of Punjab, India. A cross-sectional analytical study was carried out by using multistage random sampling technique and personally interviewing dairy farmers ( $n=600)$ from six different districts of state. Majority of farmers $(51.00 \%)$ were found aware about the technology. Overall adoption was observed around 35.00 per cent, where 13.80 and 21.20 per cent dairy farmers followed full and partial adoption respectively. Chi-square statistics indicated that the socio-economic characteristics of respondents such as age, education, family size, dairy farming experience were not significantly associated with adoption where as variables like land holding, herd size, species reared, social participation, project beneficiary, training received, extension contacts and mass media exposure were found significantly associated $(\mathrm{p}<0.01)$. Majority farmers perceived that this technology is easy to implement, divisible and reversible, cost-wise affordable, needs knowhow, reduce risk of diseases, observable in terms of outcome, reducing production cost, easy to follow up and triable. This study concluded that farmers can opt to adopt this technology if more awareness is generated along with higher accessibility at field level.

\section{Introduction}

The mainstay of the feeding system in India is fibrous feed, which forms the bulk of ruminant diets. These fibrous feeds are deficient in protein, energy and minerals, with poor palatability and digestibility. Garg et al (2007) explained that without additional supplements, such feeds cannot support even body maintenance of the animals. Urominlick (UML)/ Urea-molasses multi nutrient blocks (UMMB) are multi-nutrient blocks 
acting as a blend of energy, protein and minerals which act as an important feed supplement and life saver. It is a convenient and inexpensive technology of providing a range of nutrients to animals by improving the digestion of low-quality roughages through satisfying the requirement of rumen microorganisms, creating a better environment for fermentation and increasing production of microbial protein and volatile fatty acids. Urea, after hydrolysis to ammonia in the rumen, acts as a nitrogen source for the rumen microbes, while molasses provides readily-fermentable energy. These advantages, together with enhanced productivity in terms of increased milk and meat production and higher reproductive efficiency in ruminant animal species, that include cattle, buffalo, sheep, goats and yak, as a result of supplementation with the blocks have resulted in their adoption in over 60 countries. Many international organizations reported by Makkar (2007), including the Joint FAO/ IAEA Division (Vienna), FAO, UNDP, ACIAR and SAREC-SIDA, have played important roles in dissemination of this technology to such a large number of countries.

The problem of feeding urea to animals has been overcome in India by the introduction of feed supplementation blocks in the form of urea-molasses mineral block (UMMB) licks, as reported by Kunju, (1986a, b), developed at the National Dairy Development Board (NDDB), Anand, India. NDDB first introduced farmers to UMMBs in 1983, when they were prepared by using a "hot process" technique. Various research were carried out for standardizing the formulation of UMMBs and for developing means for their large-scale production by the "cold process". It also deals with UMMB packaging, quality control and long-term storage, and examines the licking behaviour of animals presented with these blocks under field conditions.
As explained by Wadhawa \& Bakshi 2010, UML technology encompasses supplementation of an average 500-700 g UMMB/day/animal and animals receive it by licking the conventional UMMB which weighs $3 \mathrm{~kg}$ and contains molasses $900 \mathrm{gm}$, urea $300 \mathrm{gm}$, mustard cake $300 \mathrm{gm}$, de-oiled rice bran $300 \mathrm{gm}$, wheat flour $450 \mathrm{gm}$, mineral mixture $450 \mathrm{gm}$, calcium oxide 120 gm, salt $120 \mathrm{gm}$ and guar gum $60 \mathrm{gm}$. As found by Garg et al 2007, UMMB/UL supplementation reduced Pica effectively. The animals gained better general body condition. Farmers also reported that, Cows not showing oestrus signs for a longtime (presumably due to inadequate nutrition) resumed cycling when given mineral-rich blocks. Increased milk production due to UMMB supplementation have generated additional income and improved reproductive performance, leading to more calves.

Despite these advantages, the technology has yet to reach masses as Aparna et al (2018) reported that only 13.3 per cent farmers were familiar with this technology during pretest of her study. Maleko et al (2018) also mentioned the major reasons for low adoption of proven technologies include limited technical knowhow among smallholder dairy farmers augmented by limited extension services and technological costs. With this, the present research study was planned to assess the awareness and adoption of this technology in field conditions of Punjab, India, where sustainable dairy farming is emerging as a major alternative to wheat-rice cropping system reported by Randhawa (2016), as agricultural technology has shown signs of fatigue with slow down of income growth and reduced employment, the farmers of state are willing to adopt dairy as entrepreneurship, found by Laldinpuii (2013). The various attributes of technology perceived by dairy farmers were also studied during this research. 


\section{Materials and Methods}

The proposed cross- sectional analytical study was carried out in six different districts of Punjab. A sample size of 600 farmers was calculated as per procedure followed by Dhand and Khatkar (2014) to estimate the awareness and adoption level, assuming that $50 \%$ of the farmers would have awareness and knowledge about the technology at confidence interval of four with $95 \%$ confidence level assuming a response rate of $80 \%$ and a population of 14222 households in the selected villages. Guru Angad Dev Veterinary and Animal Sciences University (GADVASU), Ludhiana, the renowned veterinary and animal scineces university in Punjab, has generated this technology of UMMB and continuously engaged in dessimination of same through its head quarter as well as through the outreach centres at different districts of the state. Districts viz. Barnala (D1), Bathinda (D2), Hoshiarpur (D3), Ludhiana (D4), Sahibzada Ajit Singh Nagar (SAS Nagar) (D5) and Tarn Taran (D6) were selected purposlively as GADVASU has its outreach centers in form of Krishi Vigyan Kendra (KVK) and Regional Research Training Centre for propoagation and dissemianation of varous technologies. Multi-stage random sampling technique was followed for selection of blocks, villages and respondents. From each selected district two blocks and two villages from each block and 25 dairy farmers from each village were selected randomly.

\section{Questionnaire design and data collection}

A semi-structured questionnaire as a research instrument/tool was designed for the purpose of collecting data from the respondents. The questionnaire comprised of both open and closed ended type of questions which included the details regarding sociodemographic and socio-economic profile of respondents consisting information regarding gender, age, family type and size, education, dairy farming experience, occupation, land holding, animal holding, species and breed of dairy animals, milk production and sale, annual family income, dairy income details, training attended, present management details etc. Technology adoption part of the questionnaire was dealt with the awareness i.e familiarity about the technology and adoption. Source of technology and duration of adoption was also recorded. Information regarding perceived attributes of technology, extension contacts, mass media exposure, institutional accessibility of the respondents were also collected. Personal interview techniques was employed for data collection. The interview was followed in local language by receiving the farmer's participatory consent for the study.

\section{Piloting of the instruments}

The questionnaire was piloted to test the reliability and validity of data. It was administered on dairy farmers of selected districts in proportion of $5 \%$ of sample size having similar characteristics as well as adjacent to the selected villages. Validation by the experts judgments was done for the research instrument. A Cronbach's alpha scale was used to study the internal consistency of the variables. The Cronbach's alpha value of the final questionnaire on technology adoption was 0.79 , indicating higher reliability of the designed questionnaire for the proposed study.

\section{Operationlisation of variables and data analysis}

A dictomous response for the awareness/familiarity in form of Yes (Score1) or No (Score-0) for each technology was recorded. A dictomous response in form of Yes (Score-1) or No (Score-0) was recorded. 
Based on the response farmers were categorized as adopter and non-adopters of technology. If the response is "Yes" for technology adoption further details of extent of adoption i.e. fully and partially adopted was recorded. The details of information about duration of adoption and source of technology from where they came to know about the technology were also recorded.

Various technology attributes as studied by Dhraief et al 2018 were selected to understand their importance on the adoption-decision of dairy farming technology (DFT). A Likert scale of five, strongly agree (5) and strongly disagree (1) was used to assess the perception of the dairy farmers about selected technologies used in dairy farming. The mean score was obtained for each perceived attribute and ranks were assigned in descending order starting from 1 for highest score.

Data was analyzed using Statistical Package for the Social Science (SPSS) version 20 developed by IBM company, USA. Descriptive statistics was applied to assess awareness, adoption and household characteristics of dairy farmers in the study area. A characterization was done using contingency tables (cross tabulation) to compare the proportion of adopters and nonadopters of the technology in respect of a particular characteristic. Chi-square test was carried out to assess association between adoption and socioeconomic variables.

\section{Results and Discussion}

The results in Table 1 represent district wise distribution of dairy farmers based on awareness about the UML technology. Majority of farmers $(51.00 \%)$ were aware about the technology of UML. Many farmers responded that they knew that the UML are being prepared and sold by Guru Angad Dev
Veterinary \& Animal Sciences university (GADVASU), Ludhiana. Awareness regarding commercial availability of such kind of multi-nutrient blocks was not reported by any respondent of this study. The significant association $(p<0.01)$ was found among different districts selected for study indicating highest awareness in Hoshiarpur district followed by Tarn Taran, Barnala, SAS Nagar, Ludhiana and Bathinda. As Hoshiarpur is one of the disadvantaged district of the state, suffer with sever fodder scarcity due to hilly region and wild life disturbance. This may be the reason that this technology is highly promoted $t$ create more awareness regarding used of UML technology to sustain the milk production with available feed and fodder.

Overall adoption for the UML technology was found around 35.00 per cent, where about 13.80 and 21.20 per cent dairy farmers followed full and partial adoption respectively (Table 2). The district-wise adoption was recorded highest in Barnala, followed by Tarn Taran, Hoshiarpur, SAS Nagar and Ludhiana. Only partial adoption was found in Bathinda district. The significant association $(\mathrm{p}<0.01)$ was found in respect of adoption of the technology among different districts. The variation in adoption might be due to availability and accessibility of technology which supports the findings of Bhattu et al (2013), who found that the availability of urea molasses mineral block (UMMB) licks was also a problem for further adoption in the study area.

The data presented in Table 3 provides the details about the source of technology i.e. from where the technology adopters got information and inputs about the dairy innovation. Around 58.00 per cent farmers received the information regarding the technology from Guru Angad Dev Veterinary \& Animal Sciences University, Ludhiana, 
while 16.20 per cent came to know through Regional Research Training Center (RRTC) located in their districts and 11.90 per cent received the knowledge through Krishi Vigyan Kendra (KVK). Around 13.80 per cent got aware through fellow farmers who were already using the technology. From the results it can be highlighted that the veterinary university is playing major role in development, propagation and dessimination of the technology at grass root level. The range for duration of adoption was found minimum six months and maximum five years with mean value of 1.5 years.

Association between socio-economic characteristics and technology adoption was studied and results are presented in Table 4. Majority of respondents belonged to $36-50$ $(43.50 \%)$ years of age, high school $(32.20 \%)$ level of education and medium size $(52.33 \%)$ family. About $2 / 3^{\text {rd }}$ respondents were engaged in agriculture activities and dairying as their occupation and possessed more than 10 years of dairy farming experience. About $30.83 \%$ farmers were small land holders followed by marginal $(21.83 \%)$, semi-medium $(21.33 \%)$, medium (12.17\%), land less (11.00\%) Majority of farmers owned medium herd size (between 6 - 15 animals) and both species at their farms. Proportionately majority of respondents had medium extension contacts and mass media exposure. Very few respondents $(12.20 \%)$ attended training. About $37 \%$ respondents had social participation and only $8 \%$ belonged to project beneficiary category.

The respondent accessibility to various institute for getting information, knowledge, training and other technical service in respect of studied technology was considered as the distance in kilometer from the GADVASU, Ludhiana, nearest KVK of the concerned district and distance from Veterinary Hospital with Which the village is attached. Majority of farmers were having medium level of accessibility to GADVASU (50.00\%), KVK $(70.80 \%)$ and Veterinary Hospital $(64.00 \%)$.

Chi-square statistics indicate that the socioeconomic characteristics of dairy farmers such as age, education, family size, dairy farming experience are not significantly associated with adoption of UML technology. The variables like land holding, herd size, species reared, social participation, project beneficiary, training received, extension contacts and mass media exposure were found significantly associated $(\mathrm{p}<0.01)$ with adoption of technology. This result indicates that these socioeconomic variables are capable of inducing change in the mental ability of the farmers which facilitate them to detect the innovations floating in the environment of their own development. As supported by Feder (1985), frequent extension visits and training affects the adoption decision positively supporting the innovation diffusion model, present findings are similar with Chug (1986), who reported significant influence of mass media exposures of the dairy farmers on the extent of adoption of technology. This is found contrary with findings of Sayeedi (1983) who stated that exposure to mass media was not found influencing on the level of adoption of the dairy husbandry practices. Similarly extension contacts also play a role in adoption as found by Nishi et al (2003). The adoption of technology was found on higher side among buffalo owners followed by both cattle and buffalo rearers. These results are in corborate with Wadhawa \& Bakshi (2011), who found that the response to supplementary feeding with UMMB was more pronounced in buffalo kept in rural areas by marginal farmers than in those kept on organised farms, which was due to the differences in basal diet of the systems.

The significant association of adoption with institutional accessibility in respect of 
distance of dairy farmer from university and $\mathrm{KVK}$, confirms that these institutes play key role in technology generation and dissemination in the study area. Khan (2007) also discussed the factors affecting adoption of UMMB technology included the price of ingredients used in UMMB, readymade availability of block, level of education and economic condition of the farmer, financial support from the Government etc.
According to Hall (2003), the choice to adopt a new technology requires knowledge that it exists and some information about its suitability to the potential adopter's situation. Therefore an important determinant of diffusion is information about the new technology, which may be influenced by the actions of the supplier of the new technology.

Table.1 District-wise distribution of farmers based on awareness of UMMB technology

\begin{tabular}{|c|c|c|c|c|c|c|c|c|}
\hline \multirow[t]{2}{*}{ Particulars } & \multicolumn{6}{|c|}{ District } & \multirow[t]{2}{*}{ Overall } & \multirow[t]{2}{*}{$\chi^{2}$ value } \\
\hline & Barnala & Bathinda & Hoshiarpur & Ludhiana & SAS Nagar & Tarn Taran & & \\
\hline Awared & $\begin{array}{c}52 \\
(17.0)\end{array}$ & $\begin{array}{c}35 \\
(11.4)\end{array}$ & $\begin{array}{c}66 \\
(21.6)\end{array}$ & $\begin{array}{c}45 \\
(14.7)\end{array}$ & $\begin{array}{c}46 \\
(15.0)\end{array}$ & $\begin{array}{c}62 \\
(20.3)\end{array}$ & $\begin{array}{c}306 \\
(51.00)\end{array}$ & \multirow[t]{2}{*}{$26.571 * *$} \\
\hline $\begin{array}{c}\text { Not } \\
\text { Awared }\end{array}$ & $\begin{array}{c}48 \\
(16.3)\end{array}$ & $\begin{array}{c}65 \\
(22.1)\end{array}$ & $\begin{array}{c}34 \\
(11.6)\end{array}$ & $\begin{array}{c}55 \\
(18.7)\end{array}$ & $\begin{array}{c}54 \\
(18.4)\end{array}$ & $\begin{array}{c}38 \\
(12.9)\end{array}$ & $\begin{array}{c}294 \\
(49.00)\end{array}$ & \\
\hline
\end{tabular}

Figures in parenthesis indicate Percentage. $* *=$ statistically significant at $1 \%$.

Table.2 District-wise Adoption of dairy farming technologies

\begin{tabular}{|c|c|c|c|c|c|c|c|c|}
\hline & \multicolumn{6}{|l|}{ District } & \multirow[t]{2}{*}{ Total } & \multirow[t]{2}{*}{$\chi^{2}$ value } \\
\hline & Barnala & Bathinda & Hoshiarpur & Ludhiana & $\begin{array}{l}\text { SAS } \\
\text { Nagar }\end{array}$ & $\begin{array}{l}\text { Tarn } \\
\text { Taran }\end{array}$ & & \\
\hline \multicolumn{9}{|l|}{ Uromin lick } \\
\hline $\begin{array}{l}\text { Fully } \\
\text { adopted }\end{array}$ & $\begin{array}{c}30 \\
(36.1)\end{array}$ & $\begin{array}{c}0 \\
(0.0)\end{array}$ & $\begin{array}{c}19 \\
(22.9)\end{array}$ & $\begin{array}{c}8 \\
(9.6)\end{array}$ & $\begin{array}{c}9 \\
(10.8)\end{array}$ & $\begin{array}{c}17 \\
(20.5)\end{array}$ & $\begin{array}{c}83 \\
(13.8)\end{array}$ & \multirow[t]{3}{*}{$72.918 * *$} \\
\hline $\begin{array}{l}\text { Partially } \\
\text { adopted }\end{array}$ & $\begin{array}{c}23 \\
(18.1)\end{array}$ & $\begin{array}{c}10 \\
(7.9)\end{array}$ & $\begin{array}{c}17 \\
(13.4)\end{array}$ & $\begin{array}{c}18 \\
(14.2)\end{array}$ & $\begin{array}{c}27 \\
(21.3)\end{array}$ & $\begin{array}{c}32 \\
(25.2)\end{array}$ & $\begin{array}{c}127 \\
(21.2)\end{array}$ & \\
\hline Not adopted & $\begin{array}{c}47 \\
(12.1)\end{array}$ & $\begin{array}{c}90 \\
(23.1)\end{array}$ & $\begin{array}{c}64 \\
(16.4)\end{array}$ & $\begin{array}{c}74 \\
(19.0)\end{array}$ & $\begin{array}{c}64 \\
(16.4)\end{array}$ & $\begin{array}{c}51 \\
(13.1)\end{array}$ & $\begin{array}{c}390 \\
(65.0)\end{array}$ & \\
\hline
\end{tabular}

Figures in parenthesis indicate Percentage. $* *=$ statistically significant at $1 \%$

Table.3 Distribution of farmers based on source of technology

\begin{tabular}{|l|c|c|}
\hline Source of technology & Frequency & Percent \\
\hline Fellow Farmer & 29 & 13.8 \\
\hline GADVASU, Ludhiana & 122 & 58.1 \\
\hline Krishi Vigyan Kendra & 25 & 11.9 \\
\hline Regional Research Training Center & 34 & 16.2 \\
\hline Total & $\mathbf{2 1 0}$ & $\mathbf{1 0 0}$ \\
\hline
\end{tabular}


Table.4 Distribution of farmers based on Socio-economic characteristics \& UML technology adoption

\begin{tabular}{|c|c|c|c|c|c|}
\hline Characteristics & Categories & Adopters & Non-adop & Overall & $\chi^{2}$ value \\
\hline \multirow[t]{3}{*}{ Age (yrs) } & Young $(<36)$ & $73(41.70)$ & $102(58.30)$ & $175(29.20)$ & \multirow[t]{3}{*}{$4.897^{\mathrm{NS}}$} \\
\hline & Middle ( $36-50)$ & $84(32.20)$ & $177(67.80)$ & $261(43.50)$ & \\
\hline & Old $(>50)$ & $53(32.30)$ & $111(67.70)$ & $164(27.30)$ & \\
\hline \multirow[t]{6}{*}{ Education level } & Illiterate (no education) & $15(23.10)$ & $50(76.90)$ & $65(10.80)$ & \multirow[t]{6}{*}{$12.225^{\mathrm{NS}}$} \\
\hline & Primary (upto $4^{\text {th }}$ ) & $21(28.40)$ & $53(71.60)$ & $74(12.30)$ & \\
\hline & Middle $\left(5^{\text {th }}-8^{\text {th }}\right)$ & $30(31.90)$ & $64(68.10)$ & $94(15.70)$ & \\
\hline & High school $\left(9^{\text {th }}-10^{\text {th }}\right)$ & $68(35.20)$ & $125(64.80)$ & $193(32.20)$ & \\
\hline & Higher secondary $\left(11^{\text {th }}-12^{\text {th }}\right)$ & $52(41.90)$ & $72(58.10)$ & $124(20.70)$ & \\
\hline & Graduate and above (above $12^{\text {th }}$ ) & $24(47.90)$ & $26(52.10)$ & $50(8.30)$ & \\
\hline \multirow[t]{3}{*}{ Family size } & Large (more than 8) & $27(32.50)$ & $56(67.50)$ & $83(13.80)$ & \multirow[t]{3}{*}{$2.600^{\mathrm{NS}}$} \\
\hline & Medium (between 5- 8) & $107(31.10)$ & $207(65.90)$ & $314(52.30)$ & \\
\hline & Small ( upto 4) & $76(37.10)$ & $127(62.90)$ & $202(33.70)$ & \\
\hline \multirow{3}{*}{$\begin{array}{l}\text { Dairy farming experience } \\
\text { (yrs) }\end{array}$} & High (more than 10) & $143(32.50)$ & $297(67.50)$ & $440(73.30)$ & \multirow[t]{3}{*}{$4.563^{\mathrm{NS}}$} \\
\hline & Medium ( between 5-10) & $46(41.40)$ & $65(57.10)$ & $111(18.50)$ & \\
\hline & Low (upto 5) & $21(42.90)$ & $28(57.10)$ & $49(8.20)$ & \\
\hline \multirow[t]{6}{*}{ Land holding (Hectors) } & Land less $(0.0)$ & $11(16.70)$ & $55(83.30)$ & $66(11.00)$ & \multirow[t]{6}{*}{$15.647 * *$} \\
\hline & Marginal $(<1.0)$ & $45(34.40)$ & $86(65.60)$ & $131(21.80)$ & \\
\hline & Small (1.1 -2.0) & $76(41.10)$ & $109(58.90)$ & $185(30.80)$ & \\
\hline & Semi-medium $(2.1-4.0)$ & $40(31.30)$ & $88(68.80)$ & $128(21.30)$ & \\
\hline & Medium $(4.1-10.0)$ & $31(42.50)$ & $42(57.50)$ & $73(12.20)$ & \\
\hline & Large $(>10.0)$ & $7(41.20)$ & $10(58.80)$ & $17(2.80)$ & \\
\hline \multirow{3}{*}{$\begin{array}{l}\text { Herz size } \\
\text { (No. of dairy animals) }\end{array}$} & Large $(>15)$ & $22(33.30)$ & $44(66.70)$ & $66(11.00)$ & \multirow[t]{3}{*}{$13.821 * *$} \\
\hline & Medium (6-15) & $132(41.50)$ & $186(58.50)$ & $318(53.00)$ & \\
\hline & Small $(<5)$ & $56(25.90)$ & $160(74.10)$ & $216(36.00)$ & \\
\hline \multirow[t]{3}{*}{ Species } & Both cattle and buffalo & $114(36.00)$ & $203(64.00)$ & $317(52.80)$ & \multirow[t]{3}{*}{$8.106^{*}$} \\
\hline & Buffalo & $75(39.50)$ & $115(60.50)$ & $190(31.70)$ & \\
\hline & Cattle & $21(22.60)$ & $72(77.40)$ & $93(15.50)$ & \\
\hline \multirow[t]{2}{*}{ Social Participation } & No & $118(31.10)$ & $262(68.90)$ & $380(63.30)$ & \multirow[t]{2}{*}{$7.098 * *$} \\
\hline & Yes & $92(41.80)$ & $128(58.20)$ & $220(36.70)$ & \\
\hline \multirow[t]{2}{*}{ Project Beneficiary } & No & $177(32.20)$ & $373(67.80)$ & $550(91.70)$ & \multirow[t]{2}{*}{$23.041 * *$} \\
\hline & Yes & $33(66.00)$ & $17(34.00)$ & $50(8.30)$ & \\
\hline \multirow{2}{*}{$\begin{array}{l}\text { Dairy farming Training } \\
\text { received }\end{array}$} & No & $175(33.20)$ & $352(66.80)$ & $527(87.80)$ & \multirow[t]{2}{*}{$6.122 *$} \\
\hline & Yes & $35(47.90)$ & $38(52.10)$ & $73(12.20)$ & \\
\hline \multirow{3}{*}{$\begin{array}{l}\text { Extension contacts } \\
\text { (Mean score) }\end{array}$} & Low $(<4)$ & $0(0.00)$ & $60(100.00)$ & $60(10.00)$ & \multirow[t]{2}{*}{$87.169 * *$} \\
\hline & Medium $(4.1-9)$ & $137(32.20)$ & $288(67.80)$ & $425(70.80)$ & \\
\hline & $\operatorname{High}(>9)$ & $73(63.50)$ & $42(36.50)$ & $115(19.20)$ & \\
\hline Mass media exposure & Low $(<4)$ & $13(16.00)$ & $68(84.00)$ & $81(13.50)$ & \\
\hline (Mean score) & Medium $(4.1-12)$ & $147(36.80)$ & $252(63.20)$ & $399(66.50)$ & $15.726 * *$ \\
\hline & High $(>12)$ & $50(41.70)$ & $70(58.30)$ & $120(20.00)$ & \\
\hline Distance from university & Short $(<66)$ & $59(39.30)$ & $91(60.70)$ & $150(25.00)$ & $18.081 * *$ \\
\hline$(\mathbf{k m s})$ & Medium $(66-151)$ & $120(40.00)$ & $180(60.00)$ & $300(50.00)$ & \\
\hline & Long $(>151)$ & $31(20.70)$ & $119(79.30)$ & $150(25.00)$ & \\
\hline Distance from KVK & Short $(<3)$ & $24(96.00)$ & $1(4.00)$ & $25(4.20)$ & $59.714 * *$ \\
\hline$(\mathbf{k m s})$ & Medium $(3-70)$ & $117(27.50)$ & $308(72.50)$ & $425(70.80)$ & \\
\hline & Long $(>70)$ & $69(46.00)$ & $81(54.00)$ & $150(25.00)$ & \\
\hline Distance from Veterinary & Short $(<1)$ & $56(45.20)$ & $68(54.80)$ & $124(20.70)$ & $7.714^{\mathrm{NS}}$ \\
\hline Hospital (kms) & Medium $(1-6)$ & $121(31.50)$ & $263(68.50)$ & $384(64.00)$ & \\
\hline & Long $(>6)$ & $33(35.90)$ & $59(64.10)$ & $92(15.30)$ & \\
\hline
\end{tabular}


Table.5 Distribution of farmers based on perceived attributes about Uromin lick technology

\begin{tabular}{|l|c|c|c|c|c|c|c|}
\hline Attributes about UL & $\begin{array}{c}\text { Strongly } \\
\text { agree }\end{array}$ & Agree & Undecided & Disagree & $\begin{array}{c}\text { Strongly } \\
\text { disagree }\end{array}$ & $\begin{array}{c}\text { Mean } \\
\text { score }\end{array}$ & RANK \\
\hline Easy to implement & 211.00 & 386.00 & 3.00 & - & - & 4.35 & I \\
\hline Easy to follow up & $(35.20)$ & $(64.30)$ & $(0.50)$ & & & & \\
\hline & 18 & 333 & 198 & 41 & 10 & 3.51 & X \\
\hline Compatible & $(3.0)$ & $(55.5)$ & $(33.0)$ & $(6.8)$ & $(1.7)$ & & \\
\hline & 196 & 14 & 331 & 49 & 10 & 3.56 & IX \\
\hline Government support & $(32.7)$ & $(2.3)$ & $(55.2)$ & $(8.2)$ & $(1.7)$ & & \\
\hline & - & 50.00 & & 550.00 & & 2.17 & XII \\
\hline Reduce risk of diseases & 81.00 & 344.00 & - & $(91.70)$ & - & & \\
\hline & $(13.50)$ & $(57.33)$ & $(22.50)$ & $(4.33)$ & $(2.33)$ & & \\
\hline Needs know-how & 47.00 & 501.00 & 29.00 & 16.00 & 7.00 & 3.94 & IV \\
\hline & $(7.83)$ & $(83.50)$ & $(4.83)$ & $(2.67)$ & $(1.17)$ & & \\
\hline Affordable cost & 75 & 464 & 22 & 39 & & 3.96 & III \\
\hline Communicability & $(12.5)$ & $(77.3)$ & $(3.7$ & $(6.5)$ & - & & \\
\hline /Observability & 37.00 & 395.00 & $73.00)$ & 71.00 & 24.00 & 3.58 & VII \\
\hline & $(6.17)$ & $(65.83)$ & $(12.17$ & $(11.83)$ & $(4.00)$ & & \\
\hline Triable & 81.00 & 338.00 & $153.00)$ & 28.00 & - & 3.79 & V \\
\hline & $(13.50)$ & $(56.33)$ & $(25.50$ & $(4.67)$ & & & \\
\hline Reduces production costs & 16.00 & 430.00 & $59.00)$ & 71.00 & 24.00 & 3.57 & VIII \\
\hline & $(2.67)$ & $(71.67)$ & $(9.83$ & $(11.83)$ & $(4.00)$ & & \\
\hline Increase profits & 81.00 & 204.00 & $264.00)$ & 33.00 & 18.00 & 3.5 & XI \\
\hline & $(13.50)$ & $(34.00)$ & $(44.00)$ & $(5.50)$ & $(3.00)$ & & \\
\hline $\begin{array}{l}\text { Divisibility } \\
\text { reversibility }\end{array}$ & 175 & 414 & 11 & - & - & 4.27 & II \\
\hline & $(29.2)$ & $(69.0)$ & $(1.8)$ & & & & \\
\hline
\end{tabular}

The results presented in Table 5 represent the distribution of farmers based on perceived attributes about the technology of uromin lick. Majority of farmers perceived that this technology is easy to implement, divisible and reversible, cost wise affordable, needs knowhow, triable, reduce risk of diseases, observable in terms of outcome, reducing production cost, easy to follow up and triable. From this it can be said that farmers can opt to adopt this technology if more awareness is generated along with higher accessibility at field level. Dhraief (2018) found that the farmers agreed to adopt feed blocks technology because it reduces risk, the technology is triable, reversible, easy to follow up and compatible with production system.
As Adesina and Zinnah (1993) discussed, the characteristics of the technology itself are also an important influence on farmers' technology adoption and usage decisions. In particular Batz et al (1999) explained that the relative complexity, risk and investment characteristics of technologies significantly affect their adoption and diffusion. From this study it can be concluded that though the technology of UML is simple, easy to implement, affordable, beneficial and reduce the risk of diseases, more extension efforts are needed to increase awareness level among farmers to achieve maximum adoption. Various factors affecting technology adoption and constraints faced by farmers in implementation has to be analysed with impact at field conditions. 


\section{References}

Adensina A A and Zinnah M M. 1993. "Technology characteristics, farmers' perceptions and adoption decisions: A Tobit model application in Sierra Leone." Agricultural Economics,13(1): 1-9.

Aparna, Kansal S K, Verma H K, Hundal J S, Singh P and Singh J. 2018. Knowledge Index of Farmers about Animal Feed Technologies during Various Training Programmes at Veterinary Varsity in Punjab, India. Int.J.Curr.Microbiol. App.Sci 7(4): 366-377

Batz F J, Peters K J and Janssen W. 1999. The Influence of Technology Characteristics on the Rate and Speed of Adoption. Agricultural Economics 21 (4): $121-$ 130

Chug, D. S. (1986). Suitability of dairy farming technology and factors affecting knowledge and adoption. M.Sc. Thesis submitted to the G. B. Pant University of Agriculture and Technology, Pantnagar

Dhand N K and Khatkar M S. 2014. Stimulator : An online statistical calculator. Sample Size Calculator for Estimating a Single Proportion.

Dhraief M Z, Bedhiaf-Romdhani S, Dhehibib $\mathrm{B}$, Oueslati-Zlaoui $\mathrm{M}$, Jebali $\mathrm{O}$ and Youssef S B. 2018. Factors affecting the adoption of innovative technologies by livestock farmers in arid area of Tunisia. FARA Research Report 3(5): 15-18.

Feder G, Just R E and Zilberman D.(1985). Adoption of agricultural innovations in developing countries : A survey, Economic Development and Cultural Change, vol. 33, 2, pp.255-298.

Garg M R, Sanyal P K and Bhanderi B M. 2007. Urea molasses mineral block supplementation in the ration of dairy animals - Indian experiences. Feed supplementation blocks; Urea-molasses multinutrient blocks: simple and effective feed supplement technology for ruminant agriculture pp 35-37. (Eds) Makkar H P S, Sanchez M and Speedy W. FAO. Animal Production and Health Paper No. 164, Rome, FAO.

Hall B H. 2003. Innovation and Diffusion. Available on www.researchgate.net /publication/5184823

Khan M A S, Chowdhury M A R, Akbar M A and Shamsuddin M. 2007. Urea molasses multinutrient blocks technology -Bangladesh experiences. Feed Supplementation Blocks-Ureamolasses multinutrient blocks: simple and effective feed supplement technology for ruminant agriculture. FAO Publication: pp. 75-88.

Kunju, P.J.G. 1986a. Urea molasses block lick: a feed supplement for ruminants. pp. 261-274, in: M.N.M. Ibrahim \& J.B. Schiere (eds). Rice straw and related feeds in ruminant rations. Proceedings of an International Workshop, Kandy, Sri Lanka, 24-28 March 1986.

Kunju, P.J.G. 1986b. Urea molasses block lick: A future animal feed supplement. Asian Livestock, 11: 154-157.

Laldinpuii N. 2013. 'Studies on dairy farming practices followed and training needs of dairy farmers in Punjab'. M.V.Sc. Thesis, Guru Angad Dev Veterinary and Animal Science University, Ludhiana, India.

Makkar H P S. (2007). Feed supplementation block technology - past, present and future. Feed Supplementation BlocksUrea-molasses multinutrient blocks: simple and effective feed supplement technology for ruminant agriculture. FAO Publication: pp. 1-12.

Malekoa D, George M, Angello M, Liliane P and Kelvin M. 2018. Smallholder dairy cattle feeding technologies and practices 
in Tanzania: failures, successes, challenges and prospects for sustainability. International Journal of Agricultural Sustainability 3: 1-13.

Nishi, Fulzele RM and Sah A K. 2003. Impact assessment of intensive mini dairy project with knowledge and adoption dimension of dairy farmers. Journal of Dairying, Foods and Home Science 22(3\&4): 251-53.

Sayeedi, A. G. (1983). A study of knowledge, attitude and adoption of dairy farmers towards dairy scientific activities in Jammu District ( $\mathrm{J} \& \mathrm{~K}$ State). A dissertation, submitted to Kurukshetra University, Kurukshetra.

Wadhwa M and Bakshi M P S. 2010. Urea- molasses-multinutrient blocks/licks: a blend of nutrients for ruminants. Proceedings of FAO Electronic Conference 30 September 2010. Successes and Failures with Animal Nutrition Practices and Technologies In Developing Countries. pp. 35-40.

Wadhwa M and Bakshi M P S. 2011. Processing and evaluation of poorquality crop residues as livestock feed, p. 51-55. In: Makkar H P S (Ed.) FAO Animal Production and Health Proceedings, 'Successes and Failures with Animal Nutrition Practices and Technologies in Developing Countries, Rome, Italy.

\section{How to cite this article:}

Vidya Nimbalkar, H. K. Verma, Jaswinder Singh. 2020. Awareness and Adoption of UreaMolasses Multi Nutrient Block (UMMB) technology in field situations of Punjab, India. Int.J.Curr.Microbiol.App.Sci. 9(01): 2170-2179. doi: https://doi.org/10.20546/ijcmas.2020.901.247 